Kamińska K., Anna Grabska, Michat Moszyński, Piotr Pysz (eds.), Stanowiony i spontaniczny tad gospodarczy w procesie transformacji systemowej Polski i bytej NRD, „Ekonomia i Prawo. Economics and Law", Polszakiewicz B., Boehlke J. (ed.), Vol. 14, No. 3/2015, pp. 389-394. DOI: http://dx.doi.org/10.12775/EiP.2015.025.

\title{
ANNA GRABSKA, MICHAŁ MOSZYŃSKI, PIOTR PYSZ (EDS.), STANOWIONY I SPONTANICZNY ŁAD GOSPODARCZY W PROCESIE TRANSFORMACJI SYSTEMOWEJ POLSKI I BYŁEJ NRD INSTYTUT BADAŃ GOSPODARCZYCH, POLSKIE TOWARZYSTWO EKONOMICZNE ODZIAŁ W TORUNIU, TORUŃ 2014
}

A monograph edited by Anna Grabska, Michał Moszyński and Piotr Pysz, titled Stanowiony $i$ spontaniczny tad gospodarczy w procesie transformacji systemowej Polski i bytej NRD (Concrete and spontaneous economic order in the course of the system transformations in Poland and the former GDR) was created as a part of an original project funded by National Science Centre in Cracow (NN 112258439) Koncepcje stanowionego i spontanicznego tadu gospodarczego w procesie transformacji systemowej gospodarki Polski i bytej NRD (The concepts of concrete and spontaneous economic order in the process of the system transformations in Poland and the former GDR).

In the introduction to monograph the authors stress, quite rightly, that in contemporary economy, it is necessary to move away from "the dominance of neoclassical monism and the neo-liberal doctrine based on the neoclassical school in favor of the transition to pluralism and competition of many schools of thought about the economy and the society" (p. 13). The interna-

Katarzyna Kamińska, Torun Higher School of Entrepreneurship, Faculty of Entrepreneurship, ul. Rybaki 57, 87-100 Toruń, Poland, phone: +48 691398 466, e-mail: kkam@mat.umk.pl. 
tional financial crisis of 2007-2009, and its consequences exposed the fundamental weaknesses of neoclassical economics and sparked a debate on the future of economics as a science. There was a huge demand for the presentation and the development of other than the mainstream schools of thought about the economy. The authors of the monograph aptly recognized this need and in their analysis focused on the issue of economic order and its transformations, illustrating their study with analysis of the market transformations in the economies of Poland and the former German Democratic Republic (GDR) between 1990 and 2010. The proposal to think in terms of economic order is an excellent tool for conducting an economic analysis, as it allows the simultaneous consideration of many aspects of economic life and their interrelationships in the long term. Its tradition is derived mainly from the work of two economists, Walter Eucken, an ordoliberalist, and Friedrich August von Hayek, an Austrian economist. Both of them claimed that the economic order is an essential category, defined as "a coherent and comprehensive set of possible formal and informal rules of the economic game" (p. 14) that have a significant impact on the economic process. As the point of reference for the conducted analysis, the authors employed Eucken's top-down economic order concept as well as von Hayek's spontaneous economic order shaped at the grass roots level. Adopting this perspective was to help to achieve the objective, namely to contribute to the concretization of both abstract order theories, thus increasing their application value for economic policy. For that purpose, the authors created a hypothesis on the existence of a feedback loop between concrete and spontaneous elements of economic order. For further discussion the authors determined that the elements of concrete economic order are created by the state and its organs, whereas the spontaneous elements come from market operators (p. 69).

The monograph consists of four chapters preceded by an introduction, and followed by the list of sources employed for its creation, which gives the total of 391 pages. The construction of the work is transparent and clear. The first chapter, by Piotr Pysz, presents the theoretical foundations of the research on concrete and spontaneous economic order in the course of the system transformations in the former GDR and Poland. It opens with a critical assessment of both academic and applied achievements of neoclassical economics and the neo-liberal doctrine stemming from it. Next, the author discusses the theories of economic order in terms of the concept of the concrete order as defined by Walter Eucken, and von Hayek's spontaneous order, including the scope of the research and the research methods employed by both economists. The author reaches an interesting conclusion here, and states that an increase in the predictive ability of economy could lead to the devel- 
opment of more realistic conceptions in economic policy, as the whole realm could evolve towards general location of its main notions within the rules of the economic game. These arguments should apply to a given economic order, existing in a given place and time, and the social and cultural context of the management process shaped by that order. Next, Pysz presents the principles of Eucken's competitive economic order, which are further analyzed in the following chapters and constitute the basic point of reference in the description of the formation of economic orders in Poland and in the former GDR. These principles include: prices as an indicator of scarcity of goods and services, a stable value of money, open markets, private ownership of the means of production, freedom of contract, financial liability for the consequences of economic activities and the stability of economic policy. Further, these principles were served as guidelines for the selection and the design of indicators to be used in order to evaluate the degree of their implementation during the analyzed period. The part that seems to be particularly interesting to the reader is devoted to the discussion on the conditions of the market system transformation processes in the post-socialist countries, with special attention to the objections towards transformational policies pursued there. The chapter closes with methodological notes clarifying the basic assumptions referring to the definitions of the elements of spontaneous and concrete order systems, the hypotheses, the research objectives, and the stages of implementation as well as the issues concerning the origin of statistical sources and the availability of data in the discussed countries.

The second chapter, by Anna Grabska, describes the determinants of the economic order in Poland during the transition period. It begins with a description of the circumstances accompanying the transformation process in Poland. Next, the author, referring to the rules of competitive order defined by Eucken, analyses the elements of concrete and spontaneous orders they determine. The element that orders the conducted analysis and enhances the readability of presented reasoning are the tables illustrating selected elements of the given order; the tables serve as the opening of every subchapter and each table clearly indicates which type of order it represents. Each section ends with a summary of the analysis carried out so far. In her conclusions towards the end of the chapter Grabska states that taking into account the trends in the changes of various determinants of concrete as well as spontaneous economic order during the analyzed period, Polish economy achieved competitive order in a very limited extent. In her opinion it was due to inadequate baseline indicators of economy, the structure of the state, and its social capital. According to the author, among the rules of order that were implemented most efficiently were prices as an indicator of scarcity of goods and 
factors of production, stable value of money, private ownership of the means of production, and open markets. The neglected aspects were in Grabska's opinion the implementation of such rules of order as material liability for the results of one's economic operations, the freedom of contract, and stable economic policy.

While reading this part of the monograph one may regret that certain facets of the analyzed issue, e.g. the analysis of fiscal policy, and the exchange rate as well as the literature on the subject were not presented in greater detail. This remark applies to the next chapter as well. Perhaps this is due to the wide dispersion of the determinants of order, which in turn hinders a more comprehensive look at the issue of stabilization policy and the presentation of deeper relations among the elements of the concrete order.

In the third chapter Michał Moszyński discusses the determinants of economic order in the process of transformation of the former GDR. This part of the monograph is very similar in its structure to the preceding chapter. Both sections have the same order of subchapters and share terminology; the only exception is the opening of chapter three, which discusses whether prices fulfill the function of the scarcity of goods and resources meter properly. These major parallels between chapters two and three certainly assist the comparison of the results of the analyses of the two countries, and help to notice the fundamental differences between the course of the transformation processes in Poland and the former GDR. When compared with the previous chapter, the recurrent difference was putting the tables illustrating the order markers in the conclusion of each subchapter, where they were accompanied by an indication whether they supported the implementation of a given rule. The third chapter opens with a description of the monetary order the former GDR and the beginning of the monetary union of 1990. Then, the author analyzes the monetary reforms in West Germany in 1948 and draws conclusions for Germany in connection with the currency reform of 1990. The next issue brought to analysis are the changes in the price relations in connection with price releases and functioning of the law of one price, and the reflections on the legislation changes and the development of anti-monopoly institutions in the new states, and the degree of fragmentation of the enterprises. Among other issues that were raised in this context one can mention the matters concerning the involvement of the state in the process of establishing the costs in the labor market as well as in agriculture and the observations about the impact of fiscal policy on the price mechanisms. Further analysis includes an evaluation of the implementation of further Eucken's competitive order rules, following the pattern presented in the second chapter. This part of the monograph, however, lacks the conclusions that would 
summarize the presented material, which may hinder the reader's comprehensive look at the results of the analysis.

Chapter four, written Piotr Pysz, is titled Stanowiony i spontaniczny tad gospodarczy w procesie transformacji Polski i bytej NRD - analiza porównawcza (Concrete and spontaneous economic order in the course of transformation in Poland and the former $G D R$ - a comparative analysis). It is divided into four subchapters. The first subchapter is an attempt to determine the extent of the occurrence of the elements characteristic for spontaneous as well as concrete economic order. The author evaluates the implementation of the cognitive tasks posed at the beginning of the monograph, summarizes the results obtained in the analysis, and draws general conclusions from the presented material. He concludes that the occurrence of various forms of economic order is mainly the result of the position and the role of the state in the economy (p. 328). At this point, the author refers to the challenges that the ordoliberal theory, and especially its father, Walter Eucken, put before the state. Pysz claims that the policy of a the state being responsible for shaping the order requires that state to be strong enough to be able to break the resistance of the existing groups of economic power and at the same time have the skill of self-limitation to shaping exclusively the economic order. In this context the author raises the question of whether and to what extent the political authorities in the former GDR and Poland wanted and were able to meet the demands created by Eucken's theory. Trying to answer the question, Pysz from the very beginning emphasizes significant differences between the modes of shaping economic order in Poland and in the former GDR, resulting from the strength and position of particular states as well as the attitudes prevailing in the societies of both countries. Then, he goes on to discuss the impact of the policy of shaping concrete order on initiating and reducing the occurrence of its spontaneous forms. In this context, Pysz draws attention to certain key similarities and differences in the implementation of Eucken's general principle of competitive economic order the countries' markets of goods and resources, their labor markets as well as the privatization policies. Another element of the presented synthesis is the answer to the question of how spontaneous elements of the economic order influenced political decisions of the concrete order. At this stage, the author notes that in both countries spontaneous elements of hope and social psychology had a significant influence in carrying out the system transformation in a radical way in such a short period of time. Another important conclusion was that in the process of transformation East German economy experienced more elements of Eucken's concrete order than von Hayek's order. In contrast, in Poland, in the process of shaping the economic order, there were a lot of elements of spontane- 
ous order. It was also noted that the interaction between the elements of the two orders was more dynamic, as in Poland this process was more dynamic and chaotic. In the conclusion the author formulates the main similarities occurring between the Polish economy and that of the former GDR. Pysz recognizes the importance of anthropological-sociological foundations of the market, namely the people themselves, and their importance in the process of shaping economic order. According to him, this raises the need for future interdisciplinary research on the nature of market order, so that the human foundation receives adequate importance.

In total, the authors were able to achieve the objective formulated in the initial part of the study. The task undertaken by them must be regarded as an ambitious and difficult one, and the attempt to accomplish it constitutes a fundamental value and novelty of this study. The very effort deserves the recognition, as this volume is the first text in Polish that strives to specify Eucken's theory of competitive order and von Hayek's theory of spontaneous order. The end result was gaining a broad perspective on the development of competitive order in Poland and the former GBR during the time of transition. The part that seems particularly interesting is the analysis of these elements of concrete and spontaneous order, which have not been widely discussed in the literature on the subject before.

The results of the conducted analysis could certainly gain even more in their cognitive value, had the research on the directions and the strength of the relationship between the elements concrete and spontaneous order been undertaken. The very declaration of the existence of such a relationship, appearing in the research hypothesis, intuitively may seem obvious enough.

The above critical remarks certainly do not undermine the overall value of the study. It can be certainly useful for practitioners of economic policy as well as wider audiences, on the one hand pointing to the areas neglected while shaping economic order in Poland, on the other hand specifying the directions of the necessary changes so as move towards the ordoliberal order model of Social Market Economy, which is required by a provision in Polish Constitution and the Treaty on European Union. 